\author{
Paulina Brodalka, Katarzyna Felisiak, Mariusz Szymczak
}

Katedra Technologii Żywności

Wydział Nauk o Żywności i Rybactwa

Zachodniopomorski Uniwersytet Technologiczny $w$ Szczecinie

Papieża Pawła VI 3, 71-450 Szczecin

E-mail: paulina.brodalka@zut.edu.pl

\title{
HYDROLIZATY BIAŁKOWE JAKO ŹRÓDŁO BIOLOGICZNIE AKTYWNYCH PEPTYDÓW - OTRZYMYWANIE I ZASTOSOWANIE W PRZEMYŚLE SPOŻYWCZYM
}

\section{BUDOWA BIAŁEK}

Białka sa naturalnymi produktami, które zbudowane sa $z$ reszt $\alpha$-L-aminokwasowych, połączonych $\mathrm{w}$ łańcuchy polipeptydowe specyficznymi wiązaniami kowalencyjnymi. Ponadto, istnieje również grupa zwiąków zaliczanych do peptydów, których skład i budowa jest tożsama $z$ białkami, jednak różnica dotyczy mniejszej liczby reszt aminokwasowych, a co za tym idzie mniejszej wielkości czasteczek, o znacznie prostszej strukturze przestrzennej. Pomimo tych różnic, nie ustalono oficjalnej granicy pomiędzy białkami a peptydami, jednak przyjęto umownie, że dany związek można nazwać białkiem, kiedy składa się $z$ ponad 100 reszt aminokwasowych, a jego masa czasteczkowa jest większa niż $10 \mathrm{kDa}$. Generalnie, liczba reszt aminokwasowych w białkach to 100-1000, a masa czasteczkowa mieści się w granicach 10-100 kDa (BAŃKOWSKI 2006).

\section{BIOLOGICZNIE AKTYWNE PEPTYDY}

Peptydy biologicznie aktywne to zwiazki, które wykazuja korzystne oddziaływane na funkcjonowanie organizmu człowieka. Sa definiowane jako fragmenty białek, które pozostaja nieaktywne w sekwencji swoich prekursorów, natomiast po uwolnieniu przez enzymy proteolityczne moga oddziaływać $z$ odpowiednimi receptorami oraz regulować funkcje fizjologiczne organizmu, wykazujac działanie: przeciwutleniające, antybakteryjne, przeciwgrzybicze, przeciwwirusowe, immu- nomodulujące, antyproliferacyjne, przeciwzakrzepowe, antykoagulacyjne, przeciwnadciśnieniowe; działają również jako inhibitory konwertazy angiotensyny (ACE-inhibitor), hemolityczne, opioidowe oraz wiażące wapń. Ocenę białka jako prekursora bioaktywnych peptydów przeprowadza się na podstawie jego profilu potencjalnej aktywności i częstości występowania w sekwencji fragmentów bioaktywnych (DAREWICZ i współaut. 2013, Szerszunowicz 2014, Pikul i Pospiech 2016). Podział biologicznie aktywnych peptydów opiera się na ich aktywności fizjologicznej, która jest większa niż aktywność ich prekursorów, od których maja mniejsza mase cząsteczkowa (SzERSzUNOWICZ 2014). Istnieje wiele klas biologicznie aktywnych peptydów, wyizolowanych $\mathrm{z}$ bakterii, grzybów, roślin i produktów zwierzęcych. W ich obrębie wyróżnia się mono- i dipeptydy oraz zwiazki złożone: liniowe lub cykliczne oligoi polipeptydy (PIKUl i Pospiech 2016). Podstawą do określania aktywności peptydów jest ich sekwencja aminokwasowa. Peptydy, które wykazuja aktywność biologiczna, zbudowane sa najczęściej $z 2$ do 9 reszt aminokwasowych, sjednak sa też takie, które maja ich w swoim składzie 20, a nawet więcej (DAREwICZ i współaut. 2013, SZERSZUNOWICZ 2014). Z kolei inni badacze wskazuja na liczbę reszt aminokwasowych w przedziale od 3 do 16 (DAREwicz i DzIUBA 2009). Badania wykazały, że najłatwiej wchłaniane $\mathrm{w}$ przewodzie pokarmowym sa peptydy zbudowane z 2-6 aminokwasów (GRIMBLE i współaut. 1986). 


\section{BUDOWA PEPTYDÓW \\ O WŁASCIWOŚCIACH \\ ANTYOKSYDACYJNYCH}

Głównymi składnikami peptydów antyoksydacyjnych sa reszty histydyny lub tyrozyny, również metioniny, cysteiny, tryptofanu i lizyny, które w postaci wolnej także wykazują aktywność przeciwutleniajaca. W przypadku tyrozyny, tryptofanu i histydyny dzieje się tak ze względu na obecność pierścienia aromatycznego $\mathrm{w}$ czasteczce. W przypadku metioniny i cysteiny wplyw ma obecność grupy tiolowej, natomiast lizyna ma w swojej budowie dodatkowa grupe aminowa $\left(\mathrm{PIH}^{\mathrm{H}}\right.$ LANTO I MÄKINEN 2013, DAREWICZ i współaut. 2016). Peptydy o właściwościach przeciwutleniajacych $\mathrm{w}$ pozycji N-końcowej zawieraja zazwyczaj reszty aminokwasów hydrofobowych, a niekiedy reszty aminokwasów kwasnych. Reszty hydrofobowe wspomagaja interakcje peptydów, np. z kwasem linolowym (Pena-Ramos I Xiong 2003). Pierwszym źródłem, z którego wyizolowano peptydy o właściwościach antyoksydacyjnych były produkty mleczarskie (BORAWSKA i współaut. 2014).

\section{SUROWCE DO PRODUKCJI HYDROLIZATÓW BIAŁKOWYCH}

Zwiazki antyoksydacyjne otrzymuje się na drodze hydrolizy enzymatycznej produktów pochodzenia zwierzęcego takich jak: mleko, krewetki, ostrobok, makrela, śledź, tuńczyk czy mintaj, oraz pochodzenia roślinnego, głównie $z$ nasion roślin oleistych, strączkowych i glonów, a także bardzo często $z$ pszenicy i soi (BORAWSKA i współaut. 2014, SZOŁTYSIK i współaut. 2016). Rozwiazaniem opartym na recyklingu jest produkcja hydrolizatów $\mathrm{z}$ surowców ubocznych przemysłu spożywczego. W taki sposób wykorzystuje się: śruty poekstrakcyjne, krew, skóry i kości. Wyróżnić można również szereg niekonwencjonalnych surowców, takich jak owady i kryl, którym przypisuje się potencjalnie duża wartość ze względu na ich wysokowartościowe białko. Niewykluczone jest, że w przyszłości surowce te nabiora innego, większego znaczenia wobec rosnacej liczby ludności na świecie i niewystarczającej produkcji białek konwencjonalnych (SZOŁTYSIK i współaut. 2016).

\section{ENZYMY PROTEOLITYCZNE}

Proteazy stanowią dużą i złożona grupe enzymów występujących w każdej komórce organizmu eukariotycznego i prokariotycznego. Reprezentuja klasę enzymów mających podstawowe znaczenie fizjologiczne, ponieważ uczestnicza $\mathrm{w}$ procesach katabolicznych

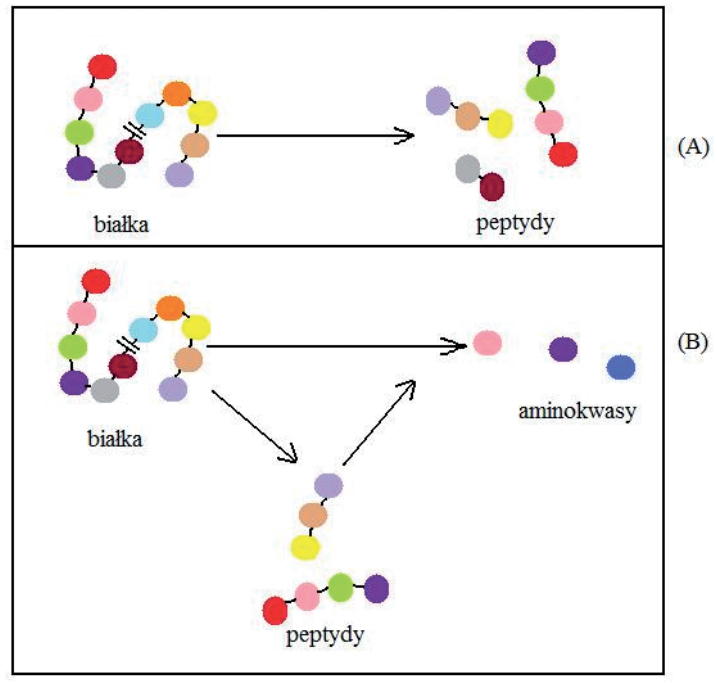

Rys. 1. Przebieg hydrolizy białka pod wpływem (a) endopeptydaz i (b) egzopeptydaz.

i regulatorowych. Ponadto, po wyizolowaniu sa wykorzystywane $\mathrm{w}$ przemyśle piekarskim, mleczarskim, browarniczym i mięsnym (RAO i współaut. 1998). Enzymy proteolityczne, z udziałem czasteczki wody, katalizuja rozrywanie wiązań peptydowych $\mathrm{w}$ białkach i peptydach. Peptydazy należą do klasy hydrolaz, stanowiac podklase czwarta - hydrolazy peptydowe (EC 3.4). Ze względu na położenie wiązania, które enzym hydrolizuje, wyróżnia się endo- i egzopeptydazy, rozrywajace odpowiednio: wiazania wewnątrz łańcucha polipeptydowego i wiąania położone skrajnie (Ryc. 1).

Do egzopeptydaz zalicza się enzymy odcinające pojedyncze aminokwasy $\mathrm{N}$-końcowe - aminopeptydazy, bądź C-końcowe - karboksypeptydazy. Ponadto, do tej grupy należą enzymy odszczepiajace jednostki dwu- i tripeptydowe (KoŁAKOWSKI 2005). Kryterium podziału w obrębie endopeptydaz jest rodzaj reszt aminokwasowych zlokalizowanych w centrum aktywnym. Wyróżnia się podklasy: serynowe (EC 3.4.21), cysteinowe (EC 3.3.22), aspartylowe (EC 3.4.23), treoninowe (EC 3.4.25), metaloproteinazy (EC 3.4.24) oraz endopeptydazy o nieznanym mechanizmie katalitycznym (EC 3.4.99). Specyficzność peptydaz w stosunku do rozkładanego substratu jest niska, jednak enzymy wykazuja preferencje $\mathrm{w}$ odniesieniu do reszt aminokwasowych, tworzacych wiazanie, na które działa enzym (BAŃKOWsKI 2006).

\section{OTRZYMYWANIE HYDROLIZATÓW BIAEKOWYCH}

Istnieje kilka sposobów uzyskiwania biologicznie aktywnych peptydów stanowiących 
produkty hydrolizy białek. Najważniejsza $Z$ fizjologicznego punktu widzenia oraz najbardziej znana i powszechna hydroliza enzymatyczna jest ta, która zachodzi bezpośrednio w przewodzie pokarmowym każdego człowieka przy udziale enzymów trawiennych (między innymi: pepsyny, trypsyny i chymotrypsyny), ale także podczas prowadzenia celowo zaprojektowanej analogicznej hydrolizy $z$ udziałem proteaz pochodzenia zwierzęcego, roślinnego i mikrobiologicznego (MinkiEWICZ I DZIUBA 2009, SZOŁTYSIK i współaut. 2012). Biologicznie aktywne peptydy moga również w dużej mierze powstawać w trakcie procesów technologicznych, np. podczas dojrzewania serów czy fermentacji mleka, nastepujacych przy zastosowaniu proteolitycznych kultur starterowych (SzERSZUNOWICZ 2014).

Pozyskiwanie preparatów białkowych zarówno $z$ surowców roślinnych, jak i zwierzęcych polega na ich ekstrakcji i wytracaniu, czego efektem jest powstanie izolatu białkowego, następnie stosuje się hydrolizę enzymatyczna (kwasowa lub zasadowa) do uzyskania hydrolizatów białkowych. Jednak powstajacca mieszanina zawiera nie tylko spodziewane zwiazki, wykazujące aktywność biologiczną. W jej skład wchodza również niezhydrolizowane białka, polipeptydy, a nawet komórki bakterii oraz enzymy i inne składniki. Zatem w celu uzyskania możliwie jak najefektywniejszych preparatów konieczne jest oczyszczanie powstałych biologicznie aktywnych peptydów (Minkiewicz i DzIUBA 2009). Surowe hydrolizaty moga być poddawane dalszej obróbce, np. inaktywacji cieplnej, ultrafiltracji, filtracji, wirowaniu, zagęszczaniu na membranach i suszeniu. Metodą najczęściej wykorzystywana do uzyskiwania formy sproszkowanej jest suszenie rozpyłowe. Najczęściej występująca i największą wada gotowego produktu sa zmiany sensoryczne, które w nim zachodza podczas hydrolizy. Proces rozkładu enzymatycznego można jednak kontrolować. Ponadto można programować otrzymanie poszczególnych frakcji o określonych masach czassteczkowych, jak również pożądanych zawartości wolnych aminokwasów, dobierając odpowiednie preparaty enzymatyczne. Poprzez modyfikację parametrów suszenia można również wpływać na cechy fizyczne produktu finalnego. Dobierając właściwie parametry procesu można modelować właściwości funkcjonalne uzyskanych preparatów. Wraz $z$ rozwojem technik separacji produktów uzyskanych podczas hydrolizy, otrzymuje się frakcje biologicznie aktywnych peptydów o coraz większym stopniu czystości (SzOŁTYSiK i współaut. 2016).

\section{WYKORZYSTANIE HYDROLIZATÓW BIAEKOWYCH W SRODKACH SPECJALNEGO PRZEZNACZENIA}

Badania nad znaczeniem różnorodnych składników żywnościowych wielokrotnie potwierdziły, że rodzaj i sposób, w jaki spożywana jest ̇̇ywność niepodważalnie wpływają na zdrowie ludzi. W zwiazku $z$ udokumentowana zależnością pomiędzy dieta a kondycja ludzkiego organizmu, w wielu krajach rozpoczęto i kontynuuje się produkcję żywności określanej mianem funkcjonalnej, która wykazuje szczególną wartość zdrowotna (SzAJDEK I BOROWSKA 2004). Uzyskuje się ja przez sterowanie właściwościami funkcjonalnymi i biologicznymi (PIKUL i POSPIECH 2016). Coraz większa część konsumentów zwraca uwagę na właściwości prozdrowotne artykułów spożywczych. Żywność o cechach funkcjonalnych gwarantuje nie tylko poprawę zdrowia, ale również jakości życia, co w obecnych czasach jest bardzo ważnym aspektem związanym $z$ higiena trybu życia. Racjonalne wydaje się być sięganie po żywność funkcjonalna ze względu na jej korzystne oddziaływanie udokumentowane w badaniach klinicznych (DAREWICZ i współaut. 2013). Właściwie każde białko może być surowcem do produkcji preparatów białkowych, które wykazują właściwości przeciwutleniajace. Znaczną część produktów spożywczych, naturalnie zawierajacych w swoim składzie biologicznie aktywne peptydy stanowia wyroby mleczarskie. Zasadne jest wykorzystanie hydrolizatów białkowych w celu modyfikacji wartości odżywczej samych środków spożywczych, jak i pochodzacych $z$ nich potraw przez poprawę jakości, zwiększenie ilości białka lub zmniejszenie zawartości składników niekorzystnych dla zdrowia. $Z$ przyczyn ekonomicznych najczęściej stosuje się hydrolizaty białkowe zastępujace drogie lub deficytowe białko. Wykorzystuje się je również $z$ myślą o grupach ludzi wymagających specjalnego odżywienia oraz przy projektowaniu mieszanek do początkowego i następnego żywienia niemowląt, a także w produktach dla sportowców, którzy potrzebuja dobrze wchłanianego i pełnowartościowego białka. Przykładem jest również stosowanie ich $\mathrm{w}$ produktach zastępujacych standardowe posiłki wykorzystywane w dietach redukcyjnych, a także w tych, z których usuwa się fenyloalaninę, stosowanych u ludzi chorujacych na fenyloketonurię (SzOŁTYSIK i współaut. 2016). Pomimo że stosowanie syntetycznych przeciwutleniaczy jest zakazane w wielu grupach żywności, to wciaż w przemyśle spożywczym dominuja one nad naturalnymi. W przypadku tych drugich często występuja problemy zwiazane $z$ pojawianiem się niepożądanych efektów 
lub zbyt słaba aktywnościa. Samo wyodrębnienie przeciwutleniaczy w czystej postaci, w szczególności $z$ surowców roślinnych, wiąże się $z$ trudnościami. Sa one gorzej rozpuszczalne, szczególnie w olejach, stosunkowo słabo oporne na podwyższona temperaturę i promieniowanie świetlne. Moga przyczyniać się do powstawania przebarwień, zwłaszcza kiedy występuja w obecności metali ciężkich, pochodzacych $z$ żywności albo $z$ opakowań, powodując zmianę barwy, smaku i aromatu (SZAJDEK i BORAWSKA 2004). Obecnie szuka się możliwości wykorzystania biologicznie aktywnych peptydów w celach terapeutycznych, ze szczególnym uwzględnieniem antybiotykoterapii i leczenia za pomoca środków przeciwgrzybicznych, a także schorzeń takich jak: zaburzenia neurologiczne, kardiologiczne, systemu odpornościowego czy zapalenia wirusowe (CicHOsz i CzECzOT 2013). Możliwości zastosowania biologicznie aktywnych peptydów o charakterze antyoksydacyjnym w zapobieganiu, a także terapii chorób cywilizacyjnych, takich, jak: zaburzenia układu sercowo-naczyniowego i choroby nowotworowe, wymaga dalszych badań, także klinicznych. Jest to szczególnie istotne w przypadku analizy uszkodzeń oksydacyjnych w obrębie DNA (DAREWICZ i DzIUBA 2009). Pomimo powszechnej opinii, że najlepszym sposobem zaspokajania potrzeb żywieniowych jest zbilansowana i racjonalna dieta składajaca się $z$ naturalnych produktów, rynek suplementów i odżywek przeżywa okres dynamicznego rozwoju. Duży udział w tym rynku maja preparaty białkowe i według prognoz będa mieć jeszcze większy, ponieważ społeczeństwo jest coraz bardziej świadome podejmowania właściwych wyborów żywieniowych i preferuje żywność wygodna. Producenci nieustannie starają się sprostać wymaganiom konsumentów i poszukuja wciąż nowych, wygodnych produktów o korzystnych właściwościach funkcjonalnych. Istnieje już wiele produktów w postaci mieszanek aminokwasów, które służą do karmienia parenteralnego (pozajelitowego). Stosuje się je u pacjentów jest w okresie okołooperacyjnym, po ciężkich zabiegach chirurgicznych, po silnych urazach lub w stanie śpiaczki. Aminokwasy w postaci żelu i tabletek do podaży dojelitowej chętnie stosuja sportowcy w celu wzbogacenia swojej diety i uzupelnienia standardowego odżywiania w okresie wzmożonego wysiłku fizycznego. Peptydy wykazujące właściwości antyoksydacyjne moga być traktowane jako potencjalne składniki suplementów. Istotne znaczenie ma zdolność wiązania kationów i udział w ich transporcie. Przykładem sa kazeinofosfopeptydy, które powstaja $z$ kazeiny $w$ obecności trypsyny i wiąża jony metali dwuwartościowych, ta- kich jak: magnez, wapń, żelazo, cynk i selen. Określone fragmenty frakcji $\alpha_{\mathrm{S} 1}$-kazeiny, $\alpha_{\mathrm{S} 2}$-kazeiny, $\beta$-kazeiny oraz $\kappa$-kazeiny wykazuja takie zdolności. Te specyficzne peptydy powoduja zwiększenie biodostępności wspomnianych jonów dwuwartościowych oraz biora udział $\mathrm{w}$ procesie remineralizacji szkliwa zębów. $\beta$-kazeina, poddana hydrolizie za pomoca trypsyny, zdolna jest do chelatowania jonów żelaza, dzięki czemu chroni wielonienasycone kwasy tłuszczowe przed utlenianiem. Aktywność in vitro peptydów pochodzacych $z$ białek mleka nie zawsze koreluje $z$ ta, która wykazuje efekty biologiczne in vivo. Zwiazane jest to $z$ mechanizmami molekularnej absorpcji i transportu, a także $z$ podatnościa peptydów na degradację $\mathrm{w}$ przewodzie pokarmowym (SzOŁTYSIK i współaut. 2016).

\section{ZNACZENIE HYDROLIZATÓW BIAEKOWYCH DODAWANYCH DO PREPARATÓW DLA OSÓB Z ALERGIA NA BIAŁKA MLEKA}

Mleko krowie jest źródłem około 20 białek, które są potencjalnymi czynnikami wyzwalajacymi reakcje uczuleniowe. W przypadku atopii objawy kliniczne pochodza ze strony układu pokarmowego, często też $z$ oddechowego, a także przybieraja postać skórną (IWANIAK i DzIUBA 2009). Część białek mleka określana jest jako alergeny główne, do których zalicza się: $\alpha$-laktoalbuminę, $\beta$-laktoglobulinę, albuminę surowicy bydlęcej, laktoferrynę bydlęca i alergeny kazeiny (UKLEJA-SOKOŁOWSKA i BARTUZI 2015). W zwiąku $z$ tym, że zdarzaja się sytuacje, kiedy matka nie może karmić dziecka naturalnie, rynek preparatów mleko-zastępczych wychodzi naprzeciw oczekiwaniom konsumentów i proponuje wiele różnych produktów wytworzonych na bazie mleka krowiego, jednak $z$ tak zmodyfikowanym składem, aby w maksymalnym stopniu przypominały mleko matki. W mieszankach mleko-zastępczych znaczaca większość substancji azotowych $(\leq 95 \%)$ stanowią peptydy o wielkości powyżej 1,5 kDa. Resztę tworza peptydy o masie cząsteczki poniżej $6 \mathrm{kDa}$. Jeśli ograniczenie $\mathrm{w}$ karmieniu naturalnym dodatkowo wiąże się $z$ ryzykiem wystapienia u dziecka alergii, korzystne jest sięganie po mieszanki mleko-zastępcze określane mianem hipoalergicznych (HA). Jest to wyjątkowa grupa preparatów zawierających krótkie peptydy lub wolne aminokwasy, przeznaczonych do karmienia niemowląt i dzieci (SzOŁTYSIK i współaut. 2016). Charakteryzują się one obniżona zawartościa peptydów o masie przekraczającej $6 \mathrm{kDa}$ i stanowią jedynie niewielka część wszystkich substancji białkowych zawartych 
w preparacie. Zawartość ta może sięgać $18 \%$, ale występuja też produkty o zawartości 2\% (HOZYASZ 2004).

Oczekiwane efekty, czyli zmniejszenie immunogenności mleka krowiego w preparacie HA, następują na skutek zmniejszenia masy molekularnej białek, a tym samym zmniejszenia właściwości alergennych (UKLEJA-SOKOŁOWSKA i BARTUZI 2015). Ponadto, częściowo zhydrolizowane białka mleka po strawieniu w świetle naczyń limfatycznych w obrębie jelit moga przyczyniać się do wytworzenia się tolerancji na białka mleka krowiego (HAYs 2005).

\section{HYDROLIZATY BIAŁKOWE JAKO DODATEK DO WYROBOW ŻYWNOŚCIOWYCH I ARTYKUŁÓW PRZEMYSŁOWYCH}

Wszystkie związi wykazujace aktywność biologiczna moga być wykorzystywane jako naturalne dodatki przy modelowaniu właściwości funkcjonalnych produktów żywnościowych. Wiele artykułów spożywczych jest podatnych na zmiany zachodzace w obrębie nienasyconych kwasów tłuszczowych w wyniku działania tlenu atmosferycznego. Zmiany te moga negatywie wpływać na jakość produktu, a szczególnie na jego cechy sensoryczne, które ulegają znacznemu pogorszeniu nawet przy niewielkich zmianach oksydacyjnych. Dodatkowo dochodzi do gromadzenia się produktów utleniania lipidów, a te moga wykazywać działanie toksyczne (SzOŁTYSIK i współaut. 2012). Enzymatyczna hydrolizę białek stosuje się w celu uszlachetnienia surowców spożywczych. Poza rolą, jaka mają do spełnienia w produktach wysokotłuszczowych, znajduja zastosowanie w technologii przetworów spożywczych, gdzie poprzez ich dodatek można uzyskać produkt o lepszej teksturze. Składniki hydrolizatów białkowych maja lepsze zdolności emulgujace, pianotwórcze i rozpraszajace, a także odznaczaja się lepsza rozpuszczalnościa w porównaniu $z$ białkami macierzystymi. Dodatkowo uzyskuje się produkty o bardziej pożądanym smaku, a także korzystniejszej wodochłonności (SzOŁTYSIK i współaut. 2016). Skrócenie łańcuchów białkowych zwykle poprawia wartość odżywcza i wzmaga walory smakowe. Należy jednak mieć na uwadze, że zbyt intensywny rozkład białek może powodować pojawienie się gorzkiego smaku. Najbardziej gorzkie sa peptydy typu: Leu-Trp, Ile-Trp, Phe-Gy-Phe-Gly i Phe-Gly-Gly-Phe. Obecny stan wiedzy pozwala na uzyskanie mieszanek o znanym, $\boldsymbol{z}$ góry założonym i zaprojektowanym składzie hydrolizatu pod względem wielkości peptydów, ich jakości, a także udziału wolnych aminokwasów (KoŁA-
KOWSKI 2005). Z ekonomicznego punktu widzenia, względne korzyści odnosi się poprzez przedłużenie trwałości produktów za pomoca dodatku hydrolizatów białkowych. Technika ta wykorzystywana jest szczególnie w przetwórstwie mięsnym, gdzie dodatkowo zwiększona jest dostępność i atrakcyjność wyrobów dla konsumentów (DAREwICZ i DZIUBA 2009). Jednak hydrolizaty białkowe znajduja szersze zastosowanie i oprócz przemysłu żywnościowego, wykorzystywane są również w przemyśle paszowym, w którym spełniaja określone funkcje, a zalicza się do nich korzystne oddziaływanie na cechy użytkowe $i$ dobrostan zwierzat w związu $z$ wpływem na florę żołądkowo-jelitowa i stopień strawności paszy. Z hydrolizatów korzysta także przemysł kosmetyczny, farmaceutyczny (produkty $z$ dużą zawartościa lipidów) i papierniczy (RADHA i współaut. 2007). Ponadto stosuje się je w produkcji farb, materiałów ulegających biodegradacji, klejów, spoiw, powłok o szczególnych właściwościach mechanicznych i barierowych, a także nanomateriałów i biopolimerów (SzOŁTYSIK i współaut. 2016).

$$
\text { Streszczenie }
$$

Białko jest w niemal wszystkich surowcach i produktach żywnościowych. Podczas składowania lub przetwarzania żywności białka często ulegaja rozkładowi na mniejsze fragmenty, do peptydów zbudowanych z kilku do kilkunastu aminokwasów. Peptydy te moga wykazywać aktywność biologiczną, korzystna dla zdrowia człowieka. Dlatego też coraz większym zainteresowaniem cieszy się żywność $z$ dodatkiem hydrolizatów białkowych. Obecnie najczęściej wykorzystuje się właściwości przeciwutleniające peptydów. Właściwości biologicznie aktywnych peptydów zależą od surowców i enzymów użytych do produkcji hydrolizatów. Sa to surowce pochodzenia zwierzęcego, jak mleko i ryby, oraz roślinnego, jak nasiona roślin oleistych, strączkowych lub zbóż. Tanim źródłem białka do produkcji hydrolizatów są również owady. Dzięki bioaktywnym peptydom, hydrolizaty białkowe pozwalają również tworzyć nową żywność projektowana dla grupy osób o specjalnych potrzebach żywieniowych, np. dla alergików.

\section{LITERATURA}

BAŃKOWsKI E., 2006. Biochemia. Podręcznik dla studentów studiów licencjackich i magisterskich. MedPharm Polska, Wrocław.

BORAWSKA J., DAREWICZ M., IWANIAK A., MINKIEWICZ P., 2014. Biologicznie aktywne peptydy. pochodzace $z$ biakek żywności jako czynniki prewencji wybranych chorób dietozależnych. Bromat. Chem. Toksykol. 47, 230-236.

CichOsz G., CZECZOT K., 2013. Żywieniowy fenomen mleka. Wydawnictwo Uniwersytetu Warmińsko-Mazurskiego, Olsztyn-Warszawa.

DAREWICZ M., DZIUBA J., 2009. Peptydy ksztaltujace właściwości smakowe. [W:] Biologicznie aktywne peptydy $i$ białka żywności. DZIUBA J., FORNAL Ł. (red.). Wydawnictwo Naukowo-Techniczne, Warszawa, 72-79.

DAREWICZ M., BORAWSKA J., MINKIEWICZ P., IWANIAK A., 2013. Peptydy aktywne biologicznie 
jako składniki żywności funkcjonalne. Technika Technologia 67, 38-41.

DAREWICZ M., BORAWSKA-DZIADKIEWICZ J., IWANIAK A., MiNKIEWICZ P., 2016.Produkty hydrolizy biakek ryb jako prewencyjne czynniki stresu oksydacyjnego oraz czynniki kardioprotekcyjne. Probl. Hig. Epidemiol. 97, 113-117.

Grimble G. K., Keohane P. P., Higains B. E., KaMINSKI M. V., SILK D. B., 1986. Effect of peptide chain length on amino acid and nitrogen absorption from two lactalbuminhydrolysates in the normal human jejunum. Clin. Sci. 71, 65-69.

HAYS T., 2005. Systematic review of the role of hydrolyzed infant formulas in allergy Prevention. Arch. Pediatr. Adolesc. Med. 159, 810819.

HOZYASZ K., 2004. Alergia na białka mleka krowiego. Rola mieszanek hipoalergicznych (HA) $w$ żywieniu niemowlat. Borgis-Nowa Pediatria $1,18-20$.

IWANIAK A., DZIUBA B., 2009. Motifs with potential physiological activity in food proteins - BIOPEP database. Acta Sci. Pol. Technol. Aliment. 8, 59-85.

KOŁAKOWSKI E., 2005. Enzymy i ich wykorzystanie $w$ modyfikacji białek żywnościowych. [W:] Enzymatyczna modyfikacja składników żyw ności. KOŁAKOWSKI E., BEDNARSKI W., BIELECKI S. (red.). WAR, Szczecin, 31-100

MinkiEWICZ P., DZIUBA J., 2009. Hydroliza enzy matyczna biakek. [W:] Biologicznie aktywne peptydy i biakka żywności. DzIUBA J., FORNAL Ł. (red.). Wydawnictwo Naukowo-Techniczne, Warszawa, 111-117.

PenA-Ramos E. A., Xiong Y. L., 2003. Whey and soy protein hydrolysates inhibit lipid oxidation in cooked pork patties. Meat Sci. 64, 259263.

Pihlanto A., MäKInEN S., 2013. Antihypertensive properties of plant protein derived peptides.
[W:] Bioactive food peptides in health disease. HERNANDEZ-LADESMA B., HSIEH C.-C. (red.). InTech, Rijeka, 145-182.

PIKUL J., PosPIECH E., 2016. Białka mleka. [W:] Białka $w$ żywności $i$ żywieniu. GAWECKI J. (red.). Wydawnictwo Uniwersytetu Przyrodniczego w Poznaniu, Poznań, 37-44.

RADHA C., KunAR P., PRAKASH V., 2007. Preparation and characterization of a protein hydrolysates from an oilseed flour mixture. Food Chem. 106, 1166-1174.

Rao M., Tanksale A., Ghatge M., Deshrande V., 1998. Molecular and biotechnological aspects of microbial proteases. Microbiol. Mol. Biol. Rev. 62, 597-635.

SZAJDEK A, BOROWSKA J., 2004. Właściwości przeciwutleniajace żywności pochodzenia roślinnego. Żywność Nauka Technologia Jakość. 4, $5-28$.

SZERSZUNOWICZ I., 2014. Wpływ peptydów uwalnianych $z$ białek mleka krowiego na układ krwionośny. Innowacyjne Mleczarstwo 2, 4-12.

SzOŁTYSIK M., NiedBalska J., DĄBROWsKa A., KuPCZYŃSKI R., ZAMBROWICZ A., POKORA M., BABIJ K., ChRZANowsKA J., 2012. Zastosowanie enzymatycznej hydrolizy kazeiny do otrzymywania peptydów o aktywności przeciwutleniajacej; Przemysł Chemiczny 91, 1014-1019.

SZOETYSIK M., KUPCZYŃSKI R., DĄBROWSKA A., ChrZANOWSKA J., FigurskA-CIURA D., ZAMBROWICZ A., BUDA B., 2016. Zastosowanie funkcjonalnych preparatów białkowo-mineralnych $w$ przemyśle żywnościowym $i$ paszowym. Przemysł Chemiczny 95, 269-273.

UKLEJA-SOKOŁOWSKA N., BARTUZI Z., 2015. Epidemiologia $i$ naturalny przebieg alergii na białka mleka krowiego. Alergia Astma Immunol. 20, 5-11.

KOSMOS Vol. 67, 4, 889-894, 2018

\title{
Paulina Brodalka, Katarzyna Felisiak, Mariusz Szymczak
}

Department of Food Science and Technology, Faculty of Food Science and Fisheries, West Pomeranian University of Technology, 3

Papiez Pawel VI Str., 71-450 Szczecin, E-mail: paulina.brodalka@zut.edu.pl

\author{
PROTEIN HYDROLYSATES AS A SOURCE OF BIOLOGICALLY ACTIVE PEPTIDES - PREPARATION AND \\ APPLICATION IN THE FOOD INDUSTRY
}

\section{Summary}

Proteins are found in almost all raw materials and food products. During the storage or processing of food, proteins are often divided into smaller fragments to peptides built from a few to a dozen of amino acids. These peptides may have biological activity that is beneficial to human health. Therefore, protein hydrolysates and foods with the addition of these hydrolysates are becoming more and more popular. Currently, the antioxidant properties of peptides are most commonly used. The properties of biologically active peptides depend on the raw materials and enzymes used to produce the hydrolysates. These are raw materials of animal origin, such as milk and fish, as well as vegetable ingredients such as oilseeds, legumes or cereals. Insects are also a cheap source of protein for the production of hydrolysates. Due to the bioactive peptides, protein hydrolysates also allow to create new foods designed for people with special nutritional needs. 